\title{
Doll's Pedagogical Theory and Its Enlightenment on British and American Literature Teaching
}

\author{
Xu Gang \\ ${ }^{1}$ Foreign Language School, Inner Mongolian University for Nationalities, China \\ Correspondence: Xu Gang, Foreign Language School, Inner Mongolian University for Nationalities, Tongliao, \\ China. Tel: 86-136-4485-2271. E-mail: steel_1232003@163.com
}

Received: December 3, 2014 Accepted: January 5, 2015 Online Published: February 13, 2015

doi:10.5539/elt.v8n3p104 URL: http://dx.doi.org/10.5539/elt.v8n3p104

\begin{abstract}
Due to the outmoded teaching method and the popularity of utilitarianism nowadays, the marginalization of British and American literature courses has become a prominent problem for the education of English majors in colleges and universities, but the American postmodern curriculum theorist, Prof. William E. Doll, Jr.'s pedagogical theory, which advocates the cultivation of students' comprehensive ability in the process of teaching, can offer great enlightenment on British and American literature teaching. So this article will apply Doll's pedagogical theory on teaching mode and academic evaluation to explore a more dynamic and instructive teaching method for British and American literature course so as to give full play to this important subject for English majors for the cultivation of their comprehensive ability, both language skills and creative thinking on literature analysis.
\end{abstract}

Keywords: Doll's Pedagogical theory, British and American literature teaching, enlightenment

\section{Introduction}

The curriculum of British and American literature is an essential course for English majors of institution of higher education, yet at present, there is a common problem in the practical teaching process, that is, the disjunction between cultivating students' humanistic literacy and promoting their comprehensive English ablities. It is mainly because of the outmoded teaching method and the popularity of utilitarianism nowadays that causes the marginalization of British and American literature courses. Yet Prof. William E. Doll, Jr., the famous American postmodern curriculum theorist, offers us an effective way for the instruction of British and American literature. Doll's Pedagogical theory advocates the cultivation of students' comprehensive ability in the process of teaching, thus it can bring positive effects to the transformation of the traditional perspectives on curriculum and instruction and help us solve the problems existing in the traditional British and American literature teaching. So this article will apply Doll's pedagogical theory on teaching mode and academic evaluation to explore a more dynamic and instructive teaching method for British and American literature course so as to give full play to this important subject for English majors for the cultivation their comprehensive ability.

\section{The Formation of Doll's Theory on Curriculum and a New Vision of British and American Teaching}

\subsection{Doll's Postmodem Curriculum Viewpoint}

Doll thinks that today's curriculum theories are based on the simple, stable and eternal cognitive vision of teaching which assumes that education is the stable, closed and equilibrated system. This does not conform to the fact that education is an open-ended process and it is in the process of constant relation adjusting: equilibrium - disequilibrium - reequilibration. After analyzing the modem curriculum in detail, Doll thinks that closeness, simplification and cumulation are the pathology of the traditional curriculum. On the contrary, postmodem curriculum should be open-ended, complicated and transformable. Open-endedness is to regard curriculum as an open system, flowing, changing. In the process of teaching interferings are necessary, they are the source of the teaching system to conduct the self-organization. Complexity means that the teaching contents are not linear and simple antagonism. Education is a process composed of the interaction of multiple elements which are netlike and the influence is synthetical. Transformation means that the process of teaching mode which changes from the stable state to a dynamic new equilibrium. So after a systematic study of the development of curriculum theories, Doll comes up with his own viewpoint with a postmodern tendency by making a creative 
integration to construct his postmodern curricular paradigm. His perspective on curriculum is the fusion of much rational thinking from various previous curriculum theories. Doll initiatively absorbs the positive factors in Schwab's practical curricular paradigm. It sees the concept of "transformation" as central to curriculum, that is, transforming curriculum materials, processes, thoughts, and participants, which mean that teachers and students need be free, encouraged, demanded to develop their own curriculum in conjoint interaction with one another.

From Piaget's "equilibrium model", Doll assimilates the concept of "self-organization", and deems it as the most concentrated embodiment of a self-improving and self-developing system. One importrant factor to make self-organization work is perturbation. "A system self-organizes only when there is a perturbation, problem, or disturbance-when the system is unsettled and needs to resettle, to continue functioning" (Doll, 1993, p. 163). As for curriculum, the existence and impact of these factors should be considered at any moment, and self-organization should be used to facilitate the saltation in the students' learning and growing process. Obviously, this viewpoint also shares the major view with A. N. Whitehead's process theory and Dewey's pragmatic curriculum theory. Drawing on Prigogine's theories of chaos and dissipative structures, Dewey's naturalism and Whitehead's process cosmology, Doll brings forward the postmodern conception of authority and control and points out that "All of these assume authority to lie within (not outside) situational parameters. Further, all assume control to be the auto- or control that emerges from interactions within these situational parameters" (Doll, 1993, p. 167). As for curriculum, here the teacher's role is restructured and resituated from being external to the student's situation to being one with that situation. The authority, too, moves into the situation. It is noteworthy that Doll absorbs Prigogine's theories of chaos and dissipative structures, which provides him a more unique angle of criticism to creatively build up his postmodern perspective on curriculum.

From Prigogine's chaos theory Doll absorbs particularly the heuristic views for curriculum, which include the views of the open-ended and changing process, the open-ended cosmological views with infinite possibilities and the views of time. Doll believes that the shift in focus from the discrete to the relational has tremendous implications for the humanities as well as the science. And at the instructional level, the implications of chaos theory deal mostly with "the concept of recursion in which the individual looks back on him or herself, and through this self-referential experience a sense of self and value emerges. Here curriculum becomes more a process of experiential transformation and less one of a set product to be mastered. Personal reflections and communal discussion of those reflections are key ingredients in this curriculum. As for Prigogine's theory of dissipative structures, Doll believes the creative paradigm of self-organization and dissipative structures has major implications for education and curriculum. First, the teaching-learning frame switches from a cause-effect one where learning is either a direct result of teaching or teaching is in a superior-inferior relationship with learning. "The switch is to a mode where teaching becomes ancillary to learning, with learning dominant, due to the individual's self-organizational abilities. Further, in this mode teaching changes from the didactic to the dialogic (Doll, 1993, p. 101). Secondly, questioning is not for efficiently achieving correct answers but for reflecting for digging deeper into the nature of the problems. The teaching role is just to fertilize certain ideas through interaction between teacher and student, but the development of these ideas is internal via the reflective process. Finally, if curriculum materials are approached iteratively, recursively, and not linearly, they can be organized to encourage such reflection, and encourage students revisit with more insight and depth what they have done.

\subsection{Doll's Theory on Curriculum and a New Vision of British and American Literature Teaching}

From the text above, we can see that Doll mainly bases on the principle of indeterminacy and the nonlinear viewpoint to form his own educational philosophy of reconstruction and sketch the framework of his postmodern curriculum theory. In the view of Doll, a postmodem curriculum must break away from the previous curriculum design, instead, he advocates a 4R Criteria for a postmodern curriculum, which includes Richness, Recursion, Relations and Rigor. Richness refers to the depth and layers of teaching contents and multiple possibilities or interpretations of a curriculum. Doll believes the "concept of developing richness through dialogue, interpretations, hypothesis generation and proving, and pattern playing can apply to all we do in curriculum" (Doll, 1993, p. 252). Richness will come from the openness and tentativeness of curriculum. This will make a multitude of areas available for cooperative dialogic exploration. Recursion is the reflective interaction with the environment, others, a culture, and with one's own knowledge. Doll thinks that Recursion can develop students' competence - the ability to organize, combine, inquire, and use something heuristically. Relations include both pedagogical relations and cultural relations. pedagogical relations refer to the relations within the curriculum which involve the interactions between teachers and students and also between the participants and teaching material; Cultural relations emphasize the relation between the historical and cultural context and the ways relations are perceived, which means we should not just confine to our own perspectives, instead we should 
integrate our indigenous perspectives into a larger social, cultural and ecological context. Rigor means "the conscious attempt to ferret out these assumptions, ones we or others hold dear, as well as negotiating passages between these assumptions, so the dialogue may be meaningful and transformative" (Doll, 1993, p. 183).

The 4R Criteria for a postmodern curriculum is quite different from the traditional curriculum requirement, thus it can offer a new vision of British and American literature teaching. In a traditional teaching and learning mode, the teacher gives lectures on the platform while the students take notes without active participating, reflecting and questioning, they often passively accept the information that the teacher feeds to them. So many students, even including some teachers, just look this subject as a copying and reciting course of British and American literary knowledge, so British and American literature course, which covers enormous social, historical, cultural and aesthetical elements, has become a heavy burden in students' eyes, thus many students lack learning interest and motivity, and the teachers often feel frustrated as well. However, based on Doll's 4R Criteria for a postmodern curriculum, British and American literature can be taught in a generative and dynamic way. It requires students' fully involvement into the teaching process, offering their own viewpoint. Accordingly, the teacher will give a timely feedback to students' comments. Furthermore, under the guidance of the teacher, British and American literature study can go beyond the confinement of classroom. Pre-reading requirements and after-class in-depth study can stimulate students' studying motivation and widen their horizon on literature works, thus facilitate the dialogue between the teacher and students as well as the dialogic relationship between students and literature works. Finally, students' spirit of reflecting, questioning, and criticizing will be cultivated, along with the improvement of their English language competence. But in order for this teaching mode to conduct smoothly, a new way evaluation for the course is needed, which must break away from the traditional evaluation stystem that focuses on the so-called standard answers and encourages rote learning. So according to Doll's postmodern perspective on curriculum, the aim of evaluation is to promote learning and inspire students rather than force students to memorize those fixed answers. Hence the evaluation of studens' study of British and American literature should be open-ended and in a plural way (a combination of class performance, mid-term test and final exam), then the evaluation can work as an effective means to test students genuine understanding of the literary knowledge and their comprehensive ablity.

All in all, Doll's postmodem view towards curriculum design, especially his generative, dialogic and heuristic education thinking, offers a new vision of British and American literature teaching on its eaching contents, teaching mode and teaching evaluation. So in the following three parts, the paper will mainly analyze the enlightenment of Doll's pedagogical theory on teaching mode and academic evaluation of British and American Literature course.

\section{Doll's Dialogic and Generative View and the Reformation of the Teaching Mode in British and American Literature Class}

The new Outline of English Teaching for English Majors of Colleges and Universities in China published in April 2000 clearly states that the aim of literature courses is to train students' ability to read, appreciate and understand the original English literary works, and master the basic knowledge and methods of literary criticism, promote the improvement of students' linguistic basic skills and the humanistic qualities, and enhance students' understanding of the western literature and culture by reading and analyzing of British and American literature. However, the present English literature instruction merely conveys the fixed literary knowledge to students, mainly aiming at helping students deal with examinations. So it relys on an independent closed system with relatively fixed teaching content, procedure and means of evaluation. The presentation of those fixed contents may improve the student's score at some time, but it can not cultivate students' capability of analysis, reflection and communication, which are of great importance to univerity students. So in general, many literature classes have a stereotyped teaching mode: the teacher relates the notes and the students take the notes; the students recite the notes before the exam and throw off the notes after the exam. The actual teaching effects of literature courses are usually far away from the requirements of the new outline. So the teaching conceptions and teaching methods of English literature instruction must be reformed.

\subsection{The Multi-Layer Dialogue and the Autonomous Learning of British and American Literature}

Apart from the traditional teacher-centered presentation, Doll's dialogic view on curriculum emphasizes more on student's autonomous study by creating a very supportive environment for autonomous learning. Hence, the teaching mode in British and American Literature class must enable students to make decisions about learning. Therefore, changing the traditional "cramming" way of teaching into the student-oriented "Participating Learning" is the important aspect of the current classroom teaching reform. The teaching mode of British and American Literature should transform from infusing templet to heuristic one, as the latter can, to the most degree, 
help students acquire knowledge and activate their thought.

According to Doll, the dialogical relation between students and texts (including the authors and the editors who edited the teaching materials) is one of the primary relations in British and American literature instruction. "By dialoguing with texts, their creators, and ourselves we come to a deeper, fuller understanding not only of issues but of ourselves, as personal and cultural beings" (Doll, 1993, p. 136). Yet in practical teaching, British and American literature instruction comprises multiple layers of dialogical relations. Besides the one between students and texts, the other relations also include the dialogue between teacher and texts; the dialogue between teachers and students; the dialogues between students. These multiple dialogic relations exist at the same time. However, they are not parallel ones, the central, basic, and ultimate one is that between students and texts, between every individual student as a subject of reading and the text as well as the author. Other layers of dialogues all function as providing certain conditions and creating a sound environment to induce and develop a dialogue between an individual student and a text. Among them, the relationship between teachers and students is the major precondition for the dialogue between students and texts. Here, the teacher is the organizer, mentor and facilitator of the students'autonomous study. According to Rodgers (1969), "the only man who is educated is the man who has learned how to learn; the man who has learned how to adapt and change; the man who has realized that no knowledge is secure, that only the process of seeking knowledge gives a basis for security" (Rogers, 1969, p. 104).

In order to motivate and facilitate dialogues between students and teachers in English literature instruction, firstly, the teaching should combine the English literature works with the social reality, life experience and the learning experience of students in teaching. Only in this way, can the course provide positive class environment which caters for learners' affective needs, and consequently, students' motivation and self-confidence, which are two important factors for eveloping learning autonomy and language learning, will be enhanced. And naturally the dialogue between teachers and students will get started. Seconldly, the dialogue between the teacher and the texts is also a prerequisite for a successful class, which means the teacher should master the course thoroughly, thus he can present a clear outline of related knowledege that is most enlightening to students, thus improving the efficiency of classroom teaching. Finally, to realize the dialogical relation between students and texts, British and American Literature class must emphasize reading process by offering students adequate time and space to experience the works and develop their literary knowledge through pre-reading and the exchanges of the whole class. Therefore, besides the high efficient classroom teaching, the supervision of out-of-class learning is also an indispensable part of British and American Literature teaching, for it can cultivate the students' awareness of autonomous learning and help them deepen what they learnt in class. The feasible practice is to encourage them to write formative evaluations such as daily or weekly diaries to monitor and analyze their learning process.

\subsection{The Generative View on Curriculum and the Formation of a Creative British and American Literature Class}

In Doll's eyes, the education system is a chaotic system. The order is not in terms of external imposition but in terms of internal harmony and balance. Thus, instruction should be a self-organizing and open system, and teachers require students to take challenge of the dynamic and generative teaching process. Doll finds that in the traditional paradigm, stability, external control, an a priori aboriginal reality areall considered self-evident. However, in a post-modem paradigm, contingency abounds. "It is common to say that in post-modernism nothing is foundational, all is relational. But it does seem that at least one concept is foundational" (Doll, 1993, p. 158). According to Doll's view curriculum designed with self-organization as a basic assumption is qualitatively different from curriculum designed with the assumption students are mere receivers. Actually challenge and perturbation is the initiator for organization and reorganization of curriculum, while in the traditional literature class, challenge and perturbation are disruptive qualities which should be overcome in curriculum design, for in a non self-organizing, closed system framework, students' challenges threaten teachers' authority, while in a self-organizing, open system framework, teachers need students' challenges in order to perform their role in the interactive process and have a generative and dynamic class.

British and American Literature teaching is a comprehensive course. Besides the exquisite texts, it's also loaded with rich social, historical and cultural significance which can not be studied as static material. It needs the participation of both teachers and students. So based on Doll's generative view on curriculum, the teaching mode of British and American Literature course should move from "linear relations" to "chaotic system". It should be open-ended, complex, and transformable. The literature instruction should be an offhand creation, and a non-linear and dynamic process during which the teacher and the students join together to create and produce the matters of the curriculum. Teaching is an offhand creation, which means its task is not to impart, but to vitalize the knowledge in such a creation; teaching is not the tool of knowledge imparting and moral education, it is generated in the collective interpretation and creation by the teacher and the students; it is dynamic, random. As 
Skinner (1953) states that in order to use the methods of science in the field of human affairs, we must assume that behavior is lawful and determined. But in fact human behavior has the uncertainty, that is, it can not be reinstated, it has only the contextual meaning and value on a certain time and at a certain place. The instructional vision which sees teaching as an offhand creation thoroughly destructs the hypothetical proposition which holds teachers are the authority of knowledge, students are the passive receivers of knowledge and teaching materials are the carriers of knowledge. So the design of English literature instruction should be dynamic and situational so that the goals of English literature teaching can be flexible and generative. The significance of a goal like this is that it can stimulate the students' interests in learning, reflecting a people-centered thinking and the features of literature. Under the guidance of traditional curriculum theories, literature teaching often pursues the clearness and precise of teaching objectives excessively, but it makes the English literature lessons lose their true colors. Hence, under the guidance of Doll's generative view on Curriculum, British and American literature class should be conducted with an open-ended goal, and the objective of English literature curriculum should be both set and generative. By saying the objective is set, we mean that the teaching should cover the major aspects of British and American literature course, socially, historically, culturally, aesthetically, etc. The so-called generativeness means that the result is not invariable, but has dynamic changes in actual teaching process. It is shaped gradually in the mutual communication between teachers and students. So the text is a multilayered, undefined and unfinished open structure, it does not have independent and free-standing significance by itself, its significance is formed in the process of reading, so the plurality, open-endedness and transformation of Doll's curriculum require the teaching not to confine itself either to the textbooks or classroom, but to look at the teaching content with open eyes. So during the process of teaching, we should draw on the postmodern process-hermeneutic thought to understand curriculum and frame a constructive and reflective curriculum matrix, for knowledge is what we create interactively, dialogically, conversationally. Everybody constructs understanding of a literary text in the context of his or her own experience so that he or she is only able to perceive a certain side of the thing. The existence of the meaning of a thing is not totally independent of us, it derives from our constructions, and everybody understands differently in his or her own way, which has been proved more often and obviously in literary learning. So students should be taught some knowledge of the western critical theories in advance so that they can have sound theoretical basis and consequently their own views on a certain literature work. And some extracurricular studying material such as those from the internet and some authentic literary journals can provide rich material for their creative study, so students should be assigned certain tasks before class to collect and analyze the related material beforehand so that they will not come to the literature class with a blank mind, and it will in turn inspire students' interests in literature learning, developing literature resources and endowing literature teaching with fresh energy and vigor.

\section{Doll's View on Academic Evaluation and the Cultivation of Students' Comprehensive Ability in British and American Literature Class}

In our present teaching system, evaluation is always associated with grades and the purpose of evaluation is mainly to distinguish winners from losers. Thus it results in the setting of some norms or specified levels of performance, as well as the so-called standard answers. Tests, grades, and other kinds of evaluation are universally used as demarcation points. Although teachers make comments on the papers or tests for students, they often focus on providing and giving some explanations about the correct or standard answers. So the traditional English literature instruction overemphasizes the imparting of knowledge and the training of skills, making the standard quantified tests almost cover the whole evaluation system with little application of other evaluation forms. The content of the traditional tests is almost all about the definitions, literary terms, the fixed information about the works and the authors and so on, which are all main points that teacher infused in the class and students remember by rote. Literature learning like this really has no much meaning.

However, Doll's view on academic evaluation is quite different from the traditional one, for the aim of Doll's evaluation is to promote learning and inspire students. Doll believes that evaluation can serve the function of distinction if necessary. However, in essence evaluation should be a negotiation process within a communal setting for the purpose of transformation. In another word, evaluation might be called transformative negotiations. The teacher plays a central role in this process but is not the exclusive evaluator. The evaluation is communal and interactive. It will be used as feedback, part of the interactive process of practicing-critiquingpracticing -critiquing. Doll believes the focus should be on a conununity dedicated to helping each individual to develop intellectual and social awareness through critique and dialogue. So Doll's perspective on academic evaluation destructs the accuracy, stability, closeness, and simplicity of the standard of traditional evaluation, for Doll emphasizes the ambiguous, dynamic, open-ended, and complex side of knowledge. Here evaluation is used more as a method of feedback. Besides, the evaluation system for English literature instruction should be 
multiple. It can be forming evaluation and conclusive evaluation; qualitative evaluation and quantitative evaluation; teacher's evaluation and student's self evaluation as well as evaluation between students. Accordingly, it can be carried out in class, before class, or after class, being adjusted according to the open-ended and generative teaching goals and the dynamic teaching process. And it should change along with the changing of the teaching methods. It should include not only the traditional written examination but also the oral examination. Obviously the aim of this kind of evaluation is not only to measure students' reading ability and writing techniques, but also to know about students' real mind by various means. Any forms of evaluation should be used to promote, improve, and guide the learning afterwards, instead of merely examining the learning and separating students with grades. At the same time, because of the speciality of literary subjects, we can not simply pursue the only answer of an English literary issue. The interpretation and discussion of English literary issues should be flexible, multiple, transforming, and open-ended. Teachers should encourage students to raise their own opinions, not to believe in blindly the answers from the specialists or teaching materials, and not to copy from the counselling books or the internet without active thinking by themselves. Since the literature teaching guided by postmodern curricular perspective pays more emphasis on student's reading process, the tests of literature curriculum should also encourage students to try their best to experience the text differently based on their own experiences and cognitive levels. As for the forms of evaluation, processive evaluation should be integrated with conclusive evaluation; individual evaluation should be banded together with communal evaluation. An open-ended, multiple, new-style educational evaluation system like this will give a new life to English literature instruction.

In practical teaching, a variety of evaluation can be applied to examine students' comprehensive ablity in literature study. Firstly, we can use the quiz in class, both written and oral ones, which can be used to test students' preparation work and their ability of understanding the new literature work just learned. In the process, the students' ability on speaking and writing can also be tested. Secondly, the midsemester examination is needed to exam students' achievements on the subject. And if there are some problems on students' study, they can be found earlier, rather than at the end of a semester. This examination can apply the form of literature commentation in order to test students' comprehensive ability on the course of British and American literature. Thirdly, final examination should the last and all-round form of evaluation on students' acedemic achievement, which can include a formal paper test of students' knowledge on some important authors and their works. This kind of examination aims to enable students to go over all the main points and make them link up each part of knowledge leamt in the whole semester to get a better grasp of knowledge with integrity and continuity. But the final score each student gets for the literature course will be a synthetic evaluation made from the above mentioned assessments. Hence, this kind of evaluation can test students' comprehensive capabilities rather than their ability of rote memorization.

\section{Conclusion}

From the analysis of Doll's Pedagogical theory, we can see that it is quite different from traditional views on curriculum. So based on Doll's pedagogical theory, the teaching of British and American literature is not only to impart knowledge, the more important commitment is to change the linear way of thinking of students formed through years of examination-oriented education. During the teaching process, the teacher should raise more questions which are open-ended instead of requiring the students to recite the so-called important points. Besides, the teacher should integrate students' life experience into the more comprehensive cultural background to interpret the literary works. In the discussion about the literary works, the open-ended discussion should be used to replace the stereotyped text analysis, making students re-organize and re-construct the meaning of the literary work through the sharing of information and critical reflection in the learning community so as to develop their creative thinking. In addition, British and American literature has its inherent system, and the content itself is relatively stable. When we stress the need to adopt a new mode of thinking to guide teaching, we actually have a higher demand for teachers. Teachers need to master the curriculum plans and curriculum standards, and be more familiar with the teaching contents, much clearer with the teaching objective. When teachers can grasp the teaching content and method very well, they must not lose sight of helping students break away from all kinds of shackles to carve out a way for their future development. Teachers should guide students in a flexible approach, make the literary knowledge become the basic quality of the teachers themselves and form their personal instructional vision and teaching methodology.

The education of the 21st century is the people-oriented education. As one of the humanistic subjects, British and American literature plays an important role in shaping the integrated personalities of students. Doll's view on curriculum is just in accordance with the requirement of the new era. It offers a new mode of teaching and means of evaluation, thus giving guidance for a more dynamic and instructive teaching method for British and 
American literature courses so as to give full play to this important subject for English majors for the cultivation their comprehensive ability, both language skills and creative thinking.

\section{Acknowledgements}

This paper is one of the phased achievements of the author for his teaching research project "The multidimensional teaching mode for British and American literature and the cultivation of students' comprehensive ability", Project No. MDYB201413.

\section{References}

Alba, A. (2000). Curriculum in the Postmodern Condition. New York: Peter Lang Publishing.

Benson, P., \& Voller, P. (1997). Autonomy and Independence in Language Learning. London: Longman.

Brown, H. D. (1987). Principles of Language Learning and Teaching. NJ: Prenrice Hall.

Brumfit, C. J., \& Carter, R. (1986). Literature and Language Teaching. Oxford: Oxford University Press.

Brumfit, C. J., \& Carter, R. (2000). Literature and Language Teaching (pp. 33-260). Shanghai: Shanghai Foreign Language Education Press.

Dickinson, L. (1987). Self-Instruction in Language Learning. Cambridge: Cambridge University Press.

Doll, W. E. Jr. (1993). A Post-modern Perspective on Curriculum. New York: Teachers College Press.

Dubin, F., \& Olshtain, E. (2002). Course Design. Shanghai: Shanghai Foreign Language Education Press.

Gardner, D., \& Miller, L. (2002). Establishing Self-access From Theory to Practice (pp. 6-178). Shanghai: Shanghai Foreign Language Education Press.

Hedge, T. (2002). Teaching and Learning in the Language Classroom (pp. 14-100). Shanghai: Shanghai Foreign Language Education Press.

Hinchey, P. H. (1998). Finding Freedom in the Classroom: A Practical Introduction to Critical Theory. Peter Lang Pub Inc.

Jacobs, D. A. (1999). Philosophy in Classroom Teaching. New Jersey: Prentice-Hall, Inc.

Liu, S., Liu, C., \& Lin, Y. (2004). New Concept for English Language Teaching and Learning (pp. 49-53). Hefei: University of Science and Technology of China Press.

O’Malley, J. M., \& Chamot, A. U. (1990). Learning Strategies in Second Language Acquisition. Cambridge: Cambridge University Press.

Pinar, W. F., \& Reynolds, W. M. (1996). Understanding Curriculum. NY: Peter Lang Publishing.

Rogers, C. R. (1969). Freedom to Learn (p. 104). Columbus Ohio: Charles E. Merrill.

Scrivener, J. (2002). Learning Teaching a Guidebook for English Language Teachers (p. 69). Shanghai: Shanghai Foreign Language Education Press.

Skinner, B. F. (1953). Science and Human Behavior. New York: Macmillan.

Stufflebeam, D. L. (1998). Conflicts between Standards-Based and Postmodernist Evaluations: Toward Rapprochement. Journal of Personnel Evaluation in Education, 12(3).

Wenden, A. L. (1985). Learner Strategies. TESOL Newsleller.

Zhu, G. (2001). Twentieth Century Western Critical Theories. Shanghai: Shanghai Foreign Language Education Press.

\section{Copyrights}

Copyright for this article is retained by the author(s), with first publication rights granted to the journal.

This is an open-access article distributed under the terms and conditions of the Creative Commons Attribution license (http://creativecommons.org/licenses/by/3.0/). 